\title{
EXPLORING THE USE OF JIGSAW WRITING AMONG ESL WRITERS: A CLASSROOM RESEARCH
}

\author{
Noor Hanim Rahmat \\ University Technology Mara, Pasir Gudang Campus, \\ Johor Bahru, Malaysia \\ E-mail: patanim@gmail.com
}

APA Citation: Rahmat, N. H. (2015). Exploring the use of jigsaw writing among ESL writers: A classroom research. Indonesian EFL Journal, 1(2), 123-134

Received: 02-12-2014

Accepted: 01-05-2015

Published: 01-07-2015

\begin{abstract}
The use of jigsaw classroom has been used by Aronson (2015) since the 1970's. It is a research based cooperative learning technique and has been successfully used in classrooms all over the world. Out of the jigsaw classroom, comes jigsaw writing and its serves the same function as cooperative learning in the classroom. The benefits of cooperative learning goes beyond learning the contents of the lessons, students gain a new way of learning in groups. Teachers teaching writing in the ESL classrooms will agree that teaching the writing process is not an easy task. ESL learners struggling with the learning of the language are faced with added difficulty of having to write essays in the ESL classroom. According to Elola (2010), collaborative writing can bring many benefits to learners in the ESL classroom. This study is based on the theories of Scaffolding and Cooperative learning. It introduces yet another interesting teaching method to make ESL writing a fun and interactive classroom activity. Qualitative and quantitative data analyzed revealed interesting implications for future teaching ESL writing.
\end{abstract}

\section{INTRODUCTION}

Tracing the Development of Teaching Writing

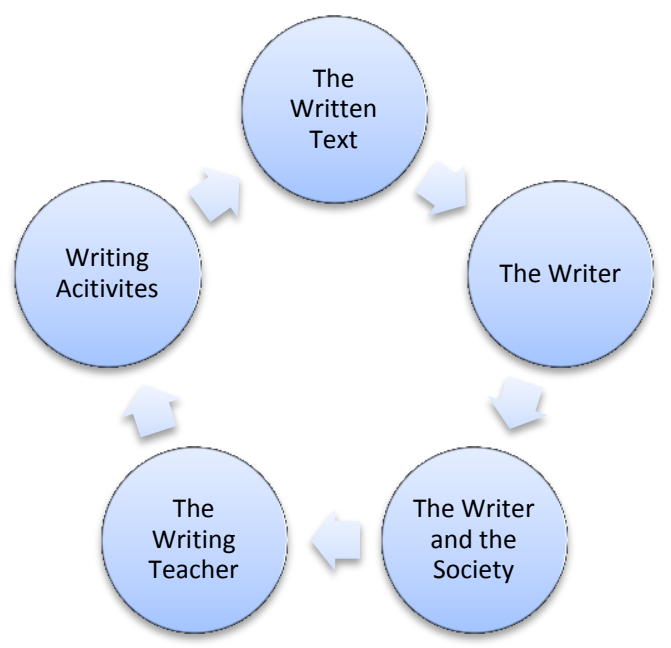

Figure 1. Development of teaching writing (Rahmat, 2008)

Figure 1 above shows the summary of development of teaching writing over the years. Initially in the in the 1960's, writers were encouraged to be creative in their writing. The focus of teaching writing during that time was the finished product of the writing. The next stage was the cognitive orientation stage (1970's). During that time, researchers began looking at what writers actually did when they wrote. The third stage was called the social Orientation Stage 1980's where writers began to consider the social context of their writing. Here the focus was writing for a purpose.

After 1990's and 2000's, researchers (and writing teachers) took a turn in their focus. From social context, the focus in writing class changed to the audience-the reader expectation. Following that, ESL writing classroom began to focus on corrective feedback-self feedback, peer feedback and also teacher feedback. Lately, many studies have been done to improve the teaching of writing in the ESL classroom.

According to the theory of principled eclecticism Larsen-Freeman (2000), teachers should consider the different trends and ideas that have occurred historically and then choose what fits the needs of their classroom setting. Over the years the focus of the writing classroom has undergone a variety of changes. As a whole, the writing classroom 
focus on many aspects such as (a) the written text, (b) the writer, (c) the writer and social context, (d) the writer and audience, (e) the writing teacher and (f) lately, the focus is on improving writing activities.

The main objective of this research is to explore the use of jigsaw writing in the ESL writing classroom. Specifically, this research looks into whether there is any significant difference between the writing process and cooperative learning in the ESL class. In addition to that, this research is also carried out to find out how jigsaw writing activities influence the writing process. It is also done to find out the influence of cooperative learning on ESL learners' writing process.

The focus in an Action Research is usually on one question, followed by subquestions to support the main focus: Hence the main research question in this study is:

1. What do the learners think of jigsaw writing?
a. Is there any significant difference between writing process and cooperative learning?
b. How does Jigsaw Writing influence the learners' Writing Process?
c. How does Cooperative Learning influence Jigsaw Writing?

\section{Teaching writing approaches}

Over the years, teaching methods have evolved from teacher centred on one end to student centred on the other end. The Product Approach (Tompkins, 1990) was reported to be mainly concerned about the structure of language and writing development is taught through the imitation of input. Process Approach (Grabe and Kaplan, 1996) allowed students to exercise their linguistic skills. Writing development is seen as the unconscious process when the teacher facilitated the writing process.

Strategic Approach (Crawford, 2004) allowed students to maximize the use of prior knowledge, and graphic organizers. In this approach, writing is coached with partners doing the think aloud protocol. Learners talked to their partners about writing and in doing so were prompted to use specific strategies to facilitate their writing process. The introduction of strategic approach also prompted teachers to focus on teaching writing for authentic purposes.

Besides Strategic approach, Crawford (2004) also introduced the Cognitive Approach. Writing here is seen as recursive and learners use graphic organizers after retrieving information from various sources. Learners were also trained to consider their potential audience before they begin to write. Teachers guided and prompted learners with ideas and suggestions for revisions. Instruction is focused on goals, and how to use the best strategies to achieve these goals. The Genre Approach (Grabe and Kaplan, 1996) is an approach that uses the Product Approach (knowledge of language) but focuses on the social purpose. The development of writing is seen as the analysis as an imitation of input. The Pragmatic Approach (Grabe and Kaplan, 1996) uses the Process view as the foundation where it concentrates on how people use language meaningfully. However, it builds on the social aspects of writing. This approach also uses whole language approach where writing is taught across the curriculum through reading, listening, writing and speaking.

The Process Genre Approach (Grabe and Kaplan, 1996) uses model for imitation. It is concerned with the knowledge about the structure of language. It focuses on the social purposes of writing and allows students to learn the process of writing. Finally, Siti Khadijah Johari (2004) introduced the concept model. This model showed that writing is done through three stages: Input, Process and Output. At the Input stage, teachers encouraged students to participate in activities that enabled them to get information to write. The Process stage made students practice the process of writing. The Output stage enabled students to display their writing to their audience.

The Writing Classroom

In Malaysia, the ESL writing classes are seen as students attempting to write about ideas and issues students neither are vaguely aware of nor interested in a language they are almost unfamiliar with. Teachers using the traditional-Behavioural (Crawford, 2004) approach in the classroom find writing difficult to teach and students find writing a 
chore. Hence, there ought to be a paradigm shift in the way writing is taught in the Malaysian classroom. Higher institutions of learning have focused the teaching to be fewer teachers centred and more students' involvement. Courses in higher institutions have made the necessary changes- student teachers have gone through necessary training. However, are these teachers using their newly acquired knowledge in the writing classroom? How are the students in the ESL writing classroom learning from teachers? Many factors play different roles to make a writing classroom conducive. Figure 2 shows the summary of vital components that make up a writing classroom. Factors like teachers' roles and responsibilities, teachers' teaching methods, learners' roles and responsibilities. In addition to that, materials used in the classroom also will make a difference in the classroom setting; hence the role of materials and how they are used.

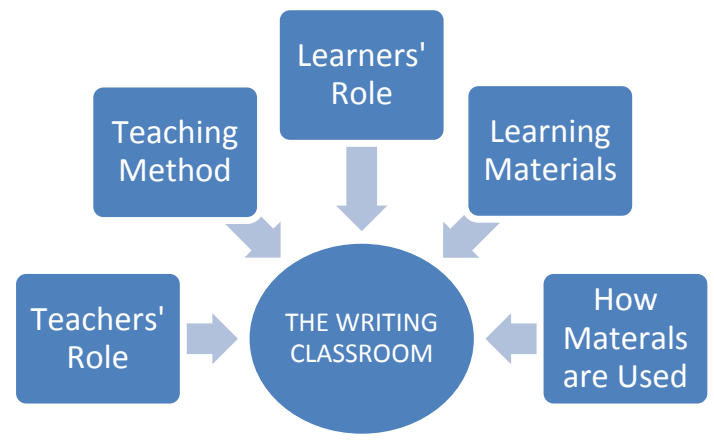

Figure 2. Components in a writing classroom The changing roles of writing teachers and materials they use

The roles and responsibilities of writing teachers have undergone transformation in many areas. To begin with teachers are more non-authoritative, they provide support and environment as well as background knowledge to the students through various activities. For example, Crawford (2004) felt that the teacher needs to support their teaching with scaffolding. In addition to that, there is also a need to teach meta-cognitive skills. Specifically, this skill includes the use of goals and strategies in a writing class. Grabe and Kaplan (1996) felt that the writing teacher needs to guide and prompt learners with ideas and suggestions for revision. Grabe and Kaplan (1996) felt that the writing teacher needs to be a planner who plans the writing class. He or she also provides opportunities for students to practice writing extensively. The teacher also provides feedback; not merely evaluates. Williams (1989) on the other hand, feels that the writing teacher needs to socialize writing and encourage students to write for social purposes.

In the Malaysian setting, Siti Khadijah (2004) feels that teacher needs to be nonauthoritative. She has to be a co-participant as well as a facilitator in the writing class. Moreover, the writing teacher needs to provide an environment for students to learn about writing, engage in writing, become enthused by writing as well as receive help during writing.

The teacher should provide background experience to the students. He or she should allow students to participate in decisions about topic, function, audience, and form. The teacher should also define writing projects clearly and specify how it will be assessed. He or she should provide opportunities for students to participate in idea gathering and organizing activities in the class.

Materials play a crucial role in making lessons successful. Textbooks are still used in many writing classroom as part of the learning process. In addition to that, course books have also made lessons successful. Some teachers also used film-related materials in the classroom to motivate students to think and write. Home-made hand-outs are also used for group activities. When choosing materials, teachers should consider the cultural content. Aspects like aesthetic sense (arts, literature, music, media, etc.), sociological sense, semantic sense as well as sociolinguistic sense need to be looked at.

In writing classrooms, various materials are used in a variety of ways. Firstly, the teacher can control the amount of help given. Here, models are used but not for all students. Students learn to get information from notes, substitution tables as well as stimuli such as maps, tables, and 
diagrams. Next, the teacher can control the interactional mode. The good students can be allowed to work on their own while the remainder of the students is organized in groups. Mixed ability interaction could take place and the harder tasks are given to the better students.

The jigsaw classroom

The concept of jigsaw classroom was first introduced by Aronson (1978) in the 1970 's. The history of its use dated back to provide an avenue for segregated students to work together for a common goal in a classroom. It is a method of organizing classroom activity that makes students' dependent on one another to succeed. It breaks the class into groups and breaks tasks into pieces and the groups later assemble to complete the puzzle. Later, results of multiple studies on the benefits of jigsaw classroom. Among them are; the activities in the jigsaw classroom allow authentic interaction among peers. This interaction can help scaffold the learners' knowledge. This helps learners build both skills and strategies. According to Vygotsky (Mcleod, 2012), "the distance between the actual developmental level as determined by independent problem solving and the level of potential development as determined through problem solving under adult guidance, or in collaboration with more capable peers." It is believed that working in groups allowed the learners to gain so much more than they would if they worked alone on the same task. Theoretical framework

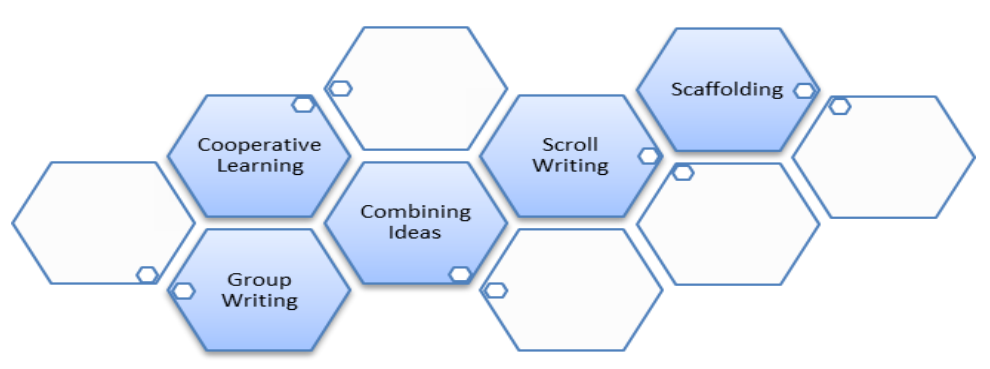

Figure 3. Theoretical framework of the study; jigsaw writing

Figure 3 above reveals the theoretical framework of the study. Jigsaw writing is a form of collaborative writing. Each member of the group works on his/her part. The decision to break the essay into parts is done from the mind map at the initial stage and this kind map acts as the scaffold towards the forming of the whole essay. The end product of the work is a combination of the works of the members in the group. Through cooperative learning, the group members learn to divide their tasks. The completed essay is actually the effort from group writing. Students work individually to form their own paragraph. The ideas are then combined -each paragraph is arranged and joined physically in a long "scroll" to make it a complete essay.

\section{Jigsaw writing}

The jigsaw technique is a method of organizing classroom activity that makes students dependent on each other to succeed. It breaks classes into groups and breaks assignments into pieces that the group assembles to complete the (jigsaw) puzzle. The idea of jigsaw activities is not competition among learners in the classroom, rather cooperating with one another to complete assigned tasks.

Jigsaw writing is also a form of collaborative writing. Each member of the group works on his/her part. The decision to break the essay into parts is done from the mind map at the initial stage and this kind map acts as the scaffold towards the forming of the whole essay. The end product of the work is a combination of the works of the members in the group. Through cooperative learning, the group members learn to divide 
their tasks. The completed essay is actually the effort from group writing. Students work individually to form their own paragraph. The ideas are then combined -each paragraph is arranged and joined physically in a long "scroll" to make it a complete essay.

\section{Cooperative learning \\ Group Writing}

The process of writing in a group can benefit learners in many ways. According to Mulligan and Garofalo (2011), group writing encourages peer interaction as well as raise learners' awareness of important organizational and syntactical elements that they otherwise might not notice on their own. In addition to that, Felder and Brent (2009) reported that learners learn more by doing things rather than learn passively.

\section{Scaffolding}

Scaffolding is a concept introduced by Vygotsky (Mc Leod, 2010). Scaffolding is best achieved when the support is matched to the needs of the learner.

\section{Combining ideas}

The study by Elola and Oskoz (2010) revealed when working in groups, the primary focus of learners would be the content and organization. Learners work together to add on to one another's existing ideas, and the combined effort can help develop a creative piece of work.

\section{Scroll writing}

A scroll is a large roll of parchment, papyrus, paper, or another flexible writing material which is used to store and display printed information (Wise Geek, 2014). In this writing class, students used sections of the mahjong paper (a large piece of paper) to write their assigned paragraphs. When everyone has completed their paragraphs, the sections are joined together this forming a long essay in the form of a scroll.

\section{Past research}

Past research has revealed benefits of cooperative learning, and especially collaborative writing. The research by Elola and Oskoz (2010) looked at the differences between writing individually and writing collaboratively. The study explored ESL learners' collaborative interactions when discussion content, structure and other aspects related to elaboration of writing. Although the data did not reveal significant differences in terms of fluency, accuracy and complexity when comparing individual and collaborative assignments, there were observable differences in terms of learners' interactions with the text as well as differences in the written product as individual writers and group writers. Their study revealed that when learners work collaboratively, they focus more on content and organization. The research also concluded that peer interaction is useful to encourage learning to take place. In addition to that, the research by Mulligan and Garofola (2011) looked at group writing at a private university in Kyoto. The learners were divided into 4 groups. Each group ranged from 20-35 students. Each group was assigned writing tasks and allowed to interact to improve on their writing. The findings revealed that collaborative writing is a non-threatening approach for students. Students enjoyed the sharing of ideas and found writing less stressful.

\section{METHOD}

Research design

This action research is an exploratory study of the use of Jigsaw Writing (often called "The Scroll Essay" by students) in the ESL classroom. The framework is shown in Figure 4. This Action Research is carried out based on the four basic action research cyclePlan, Action, Monitor and Reflection.

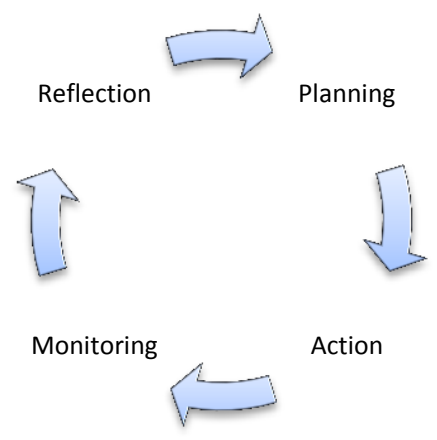

Figure 4. Research framework 


\section{Planning}

Planning of the lesson is done.

Students are given the essay title to work on. Each group has about 4-6 students. Each group is responsible to complete an essay, and each student is responsible to write a paragraph. They end the Planning by displaying their group's mind map as a signal they are ready to proceed to the next stage. Action

Each student in the group will write a paragraph- for a 5 paragraph essay-each person writes one paragraph on a paper. For example, an idea group is 5 people-one will write the introductory paragraph, another 3 persons will write a developmental paragraph each, and finally one person writes the concluding paragraph. After that, all the 5 paragraphs are combined (pasted into a long scroll) and thus become a complete essay.

\section{Monitoring}

Monitoring stage is done when the "scroll" pasted on the wall and the peers (and the teacher) make comments on the essay done. This stage is a "noisy" stage where writers defended their work, and readers made comments.

\section{Reflection}

Students reflect on the comments and made changes. Students reflect on their favorite/least favorite stage of this "scroll" writing activity. The responded to the questionnaire provided. They also wrote their comments in their journal.

\section{Respondents}

30 Diploma in Business Studies students enrolled in an ESL Academic Writing class; 18 are female students and 12 are male students.

\section{Instruments}

There are two major instruments used in this research - a questionnaire and students' journal. The questionnaire is divided into three sections; section $\mathrm{A}$ is the demographic profile, section $B$ looks at the Writing Process of the learners while section $\mathrm{C}$ elicits responses from learners about cooperative learning.

\section{Method of data analysis}

Quantitative-students' responses to the questionnaire is analyzed using SPSS.

Qualitative-After going through a cycle of Jigsaw Writing, the students wrote in their journals about what they think of Jigsaw Writing. The entries are analyzed based on recurring patterns and the patterns are then analyzed according to percentage and frequency.

\section{RESULTS \& DISCUSSION}

The discussion of findings is done based on the sub-research questions. The data collected was triangulated using instruments like questionnaire and students' journal. The discussion in this section will thus be done to reveal both quantitative and qualitative analysis of data. The main research question for this action research is:

1. What do the learners think of jigsaw writing?

This question will be answered by analyzing three (3) sub-components and they are:

a. Is there any significant difference between writing process and cooperative learning?

b. How does Jigsaw Writing influence the learners' Writing Process?

c. How does Cooperative Learning influence Jigsaw Writing?

Answer to (a) Is there any significant difference between writing process and cooperative learning?

\begin{tabular}{cccc}
\hline \multirow{2}{*}{ WRITING } & & WRITING & COOPERATIVE \\
\hline & Pearson Correlation & 1 & $.544^{*}$ \\
\cline { 2 - 4 } & Sig. (2-tailed) & & .011 \\
\cline { 2 - 4 } & $\mathrm{N}$ & 21 & 21 \\
\hline \multirow{2}{*}{ COOPERATIVE } & Pearson Correlation & $.544^{*}$ & 1 \\
\cline { 2 - 4 } & Sig. (2-tailed) & .011 & \\
\hline
\end{tabular}


Figure 5. Correlations between writing and cooperative learning

To determine if there is a significant association in the mean scores between writing and cooperative, correlation coefficient was conducted. Figure 5 shows that there is a moderate significant association between writing and cooperative learning $(\mathrm{r}=.544)$ and $(\mathrm{p}=.011)$. The correlation coefficient is significant at the 0.05 level. The coefficient of determination between the two variables has shown that only $29.6 \%$ of the rate of writing can be explained from the cooperative and vice versa. Therefore, initial findings reveal that cooperative learning can positively influence students writing process. This finding is in accordance with the research by Elola and
Oskoz (2010) who found observable difference between writing individually and in groups. The research also revealed that students writing in groups will focus on content and organization.

\section{Answer to (b)}

How does Jigsaw Writing influence the learners' Writing Process?

This question will be analyzed into two (2) sections. The first section (i) reports quantitative findings from the questionnaire. The section (ii) reports findings using the Action Research cycle and reporting on students' journal.

(i) Quantitative Findings (Questionnaire)

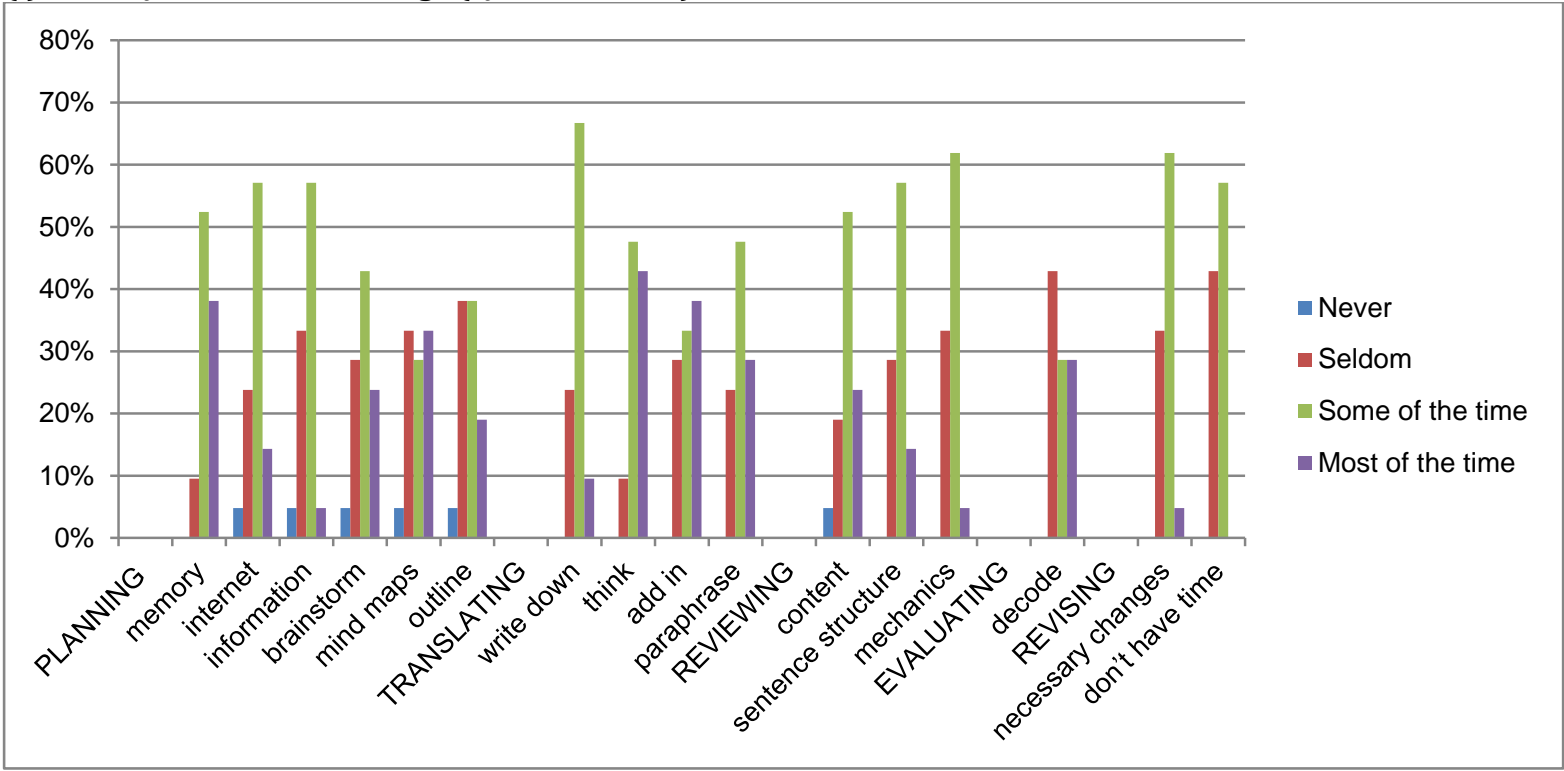

Figure 6. Percentage for writing process

According to Flower and Hayes (1981), the writing process is divided into three partsPlanning, Translating, Reviewing and Evaluating. Both quantitative and qualitative findings will be discussed based on the four sub-categories. Figure 6 reveals the percentage for writing process. During the Planning stage, learners preferred to use their memory (38.1\%), and mind maps (33.3\%). During the Translating stage, students reported that they will think about the ideas first before writing them down in sentences (42.9\%). In addition to that, students reported that the Reviewed the content (23.8\%). Group work has also been reported by Elola and Oskoz (2010) and Mulligan and Garafalo (2011) for helping students improve on their ideas some important organizational aspects of the essay.

(ii) Explaining the Action Research Cycle (Students' Journal) Planning Stage 
For the planning, stage, students were taught the Mind Map. Each group is required to prepare a Mind Map for presentation.

Table 7. Planning stage

\begin{tabular}{ll}
\hline \multicolumn{1}{c}{ Comments } & Frequency (\%) \\
\hline Attract students & $3 \%$ \\
\hline Share Ideas & $11 \%$ \\
\hline More Information presented and saves time & $2.4 \%$ \\
\hline & $16.4 \%$ \\
\hline
\end{tabular}

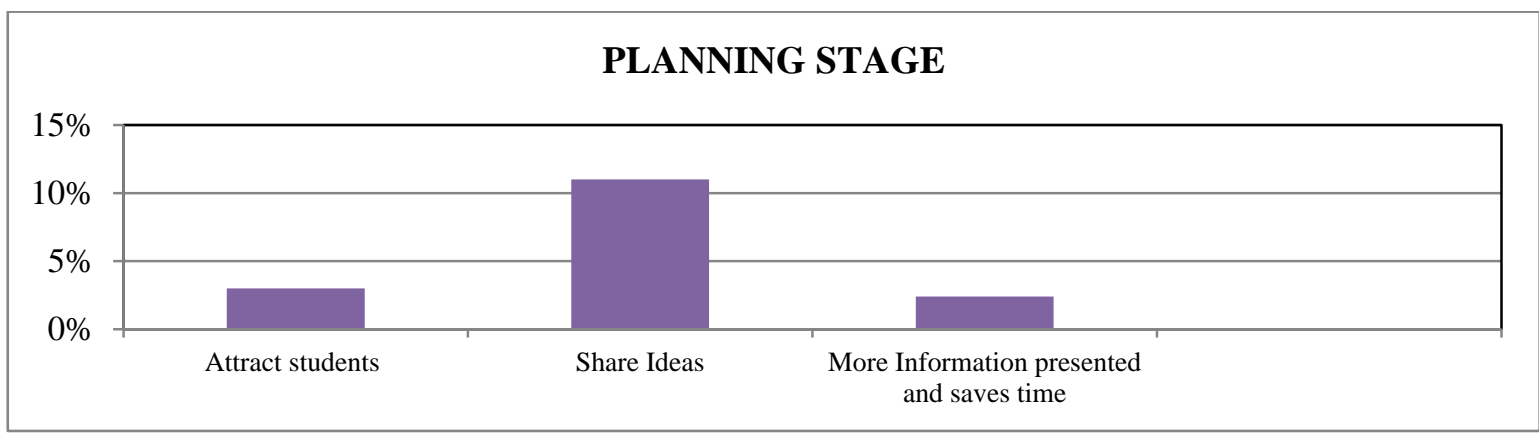

Figure 7. Planning stage

Table and Figure 7 show the response for Planning Stage. 3\% of the students felt that the planning activities attracted them towards the writing of the essay. Comments like "strongly suggest", and "I think it is good and kind of a new way to attract students in writing an essay". 11\% said that the planning stage activities allow them to share ideas. Comments written were "I think the group sharing of mind map is good. Student can share any ideas" and "can share idea" Only $2.4 \%$ of the students said they could present more information and the activity saves their writing time. This finding is in accordance with the research by Mulligan and Garofalo (2011) who found that students enjoyed group activities because as they could share ideas and gain more information than they could when they are on their own.

\section{Action stage}

Table 8. Action stage

\begin{tabular}{|c|c|}
\hline Comments & Frequency (\%) \\
\hline \multicolumn{2}{|l|}{ DIVIDING BY PARAGRAPH } \\
\hline Saves time & $4.9 \%$ \\
\hline Easier to write whole essay & $8.6 \%$ \\
\hline Learn about planning & $1.8 \%$ \\
\hline \multirow[t]{2}{*}{ focussed } & $1.8 \%$ \\
\hline & $17.1 \%$ \\
\hline \multicolumn{2}{|l|}{ PASTING PARTS } \\
\hline Combination of different sources & $1.8 \%$ \\
\hline Saves time & $1.8 \%$ \\
\hline Increase cooperation & $0.6 \%$ \\
\hline Improve comprehension & $0.6 \%$ \\
\hline Not complicated & $1.2 \%$ \\
\hline Understand the roles of paragraphs & $0.6 \%$ \\
\hline fun & $4.3 \%$ \\
\hline \multirow[t]{2}{*}{ Complete different task together } & $7.5 \%$ \\
\hline & $18.3 \%$ \\
\hline GRAND TOTAL & $35.4 \%$ \\
\hline
\end{tabular}




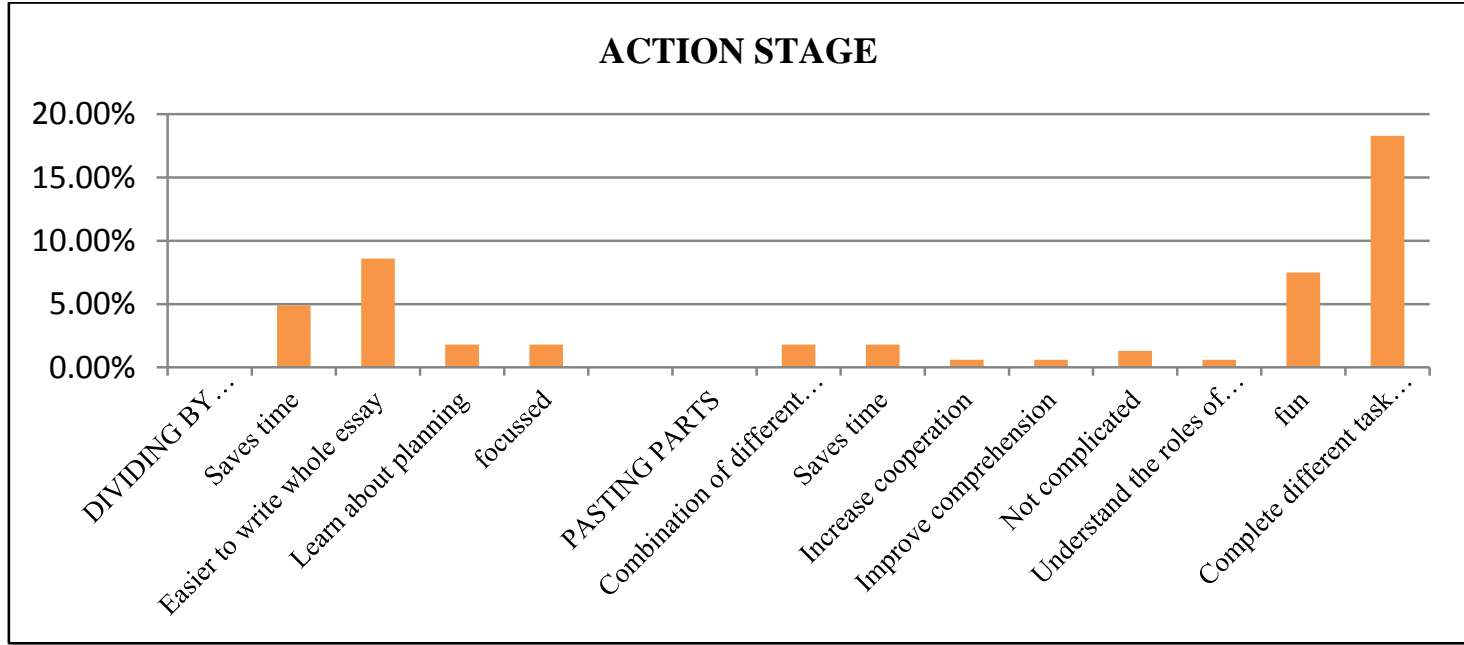

Figure 8. Action stage

Table and Figure 8 reveal the comments made about the Action Stage. This Action stage is divided into two stages-the first part is when the students were given individual task of writing a paragraph on their own. The next stage is the part where the students compiled the group members' paragraphs and paste into an essay. It is joined together using a tape and it looked like a long scroll. More comments were made for the "pasting part" $18.3 \%$ ) compared to the "dividing into paragraph" (17.1\%). Students felt that the "dividing into paragraph" part made it easier for them to write the whole essay. They also felt that "pasting" and combining the paragraphs allowed them to "complete different tasks together" (7.5\%). The concept of jigsaw classroom was first introduced by Aronson (1979) and it involves combining smaller tasks by different people to form a complete task. One of the most obvious benefits is the sharing of ideas and sharing of responsibility by different members in a group.

\section{Monitoring stage}

Table 9. Monitoring stage

\begin{tabular}{lll}
\hline & \multicolumn{1}{c}{ Comments } & Frequency (\%) \\
\hline Learn from mistakes & $11 \%$ & \\
\hline More information & $4.9 \%$ \\
\hline See friends present & $1.8 \%$ \\
\hline
\end{tabular}

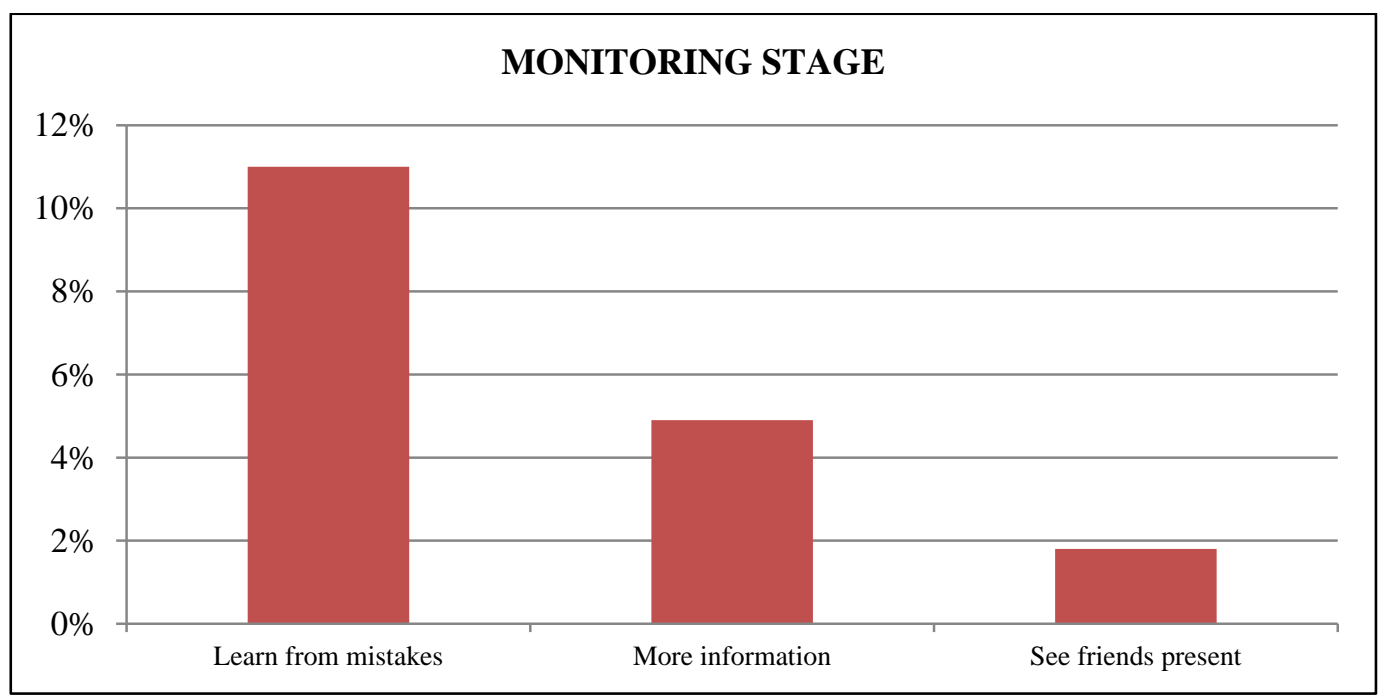


Figure 9. Monitoring stage

Table and Figure 7 show the comments for Monitoring stage. $11 \%$ of the students felt they learnt from the mistakes they or their friends made. At this stage, students displayed their scrolls to be read and commented on by their friends (and teacher). They said that this stage "is useful because we can know what the wrong and right about the essay". $4.9 \%$ felt that this stage enabled them to gain more information.

\section{Reflection stage}

Table 10. Reflection stage

\begin{tabular}{|c|c|}
\hline 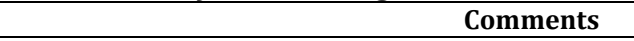 & Frequency (\%) \\
\hline \multicolumn{2}{|l|}{ LIKE MOST } \\
\hline First sentence & $1.8 \%$ \\
\hline Conclusion & $4.3 \%$ \\
\hline Introduction & $6.1 \%$ \\
\hline Pasting & $0.6 \%$ \\
\hline Explanation & $1.2 \%$ \\
\hline \multirow[t]{2}{*}{ Mind Map } & $0.6 \%$ \\
\hline & $14.6 \%$ \\
\hline \multicolumn{2}{|l|}{ HATE MOST } \\
\hline Introduction & $4.9 \%$ \\
\hline Conclusion & $3.7 \%$ \\
\hline \multirow[t]{2}{*}{ Content } & $7.3 \%$ \\
\hline & $15.9 \%$ \\
\hline GRAND TOTAL & $30.5 \%$ \\
\hline
\end{tabular}

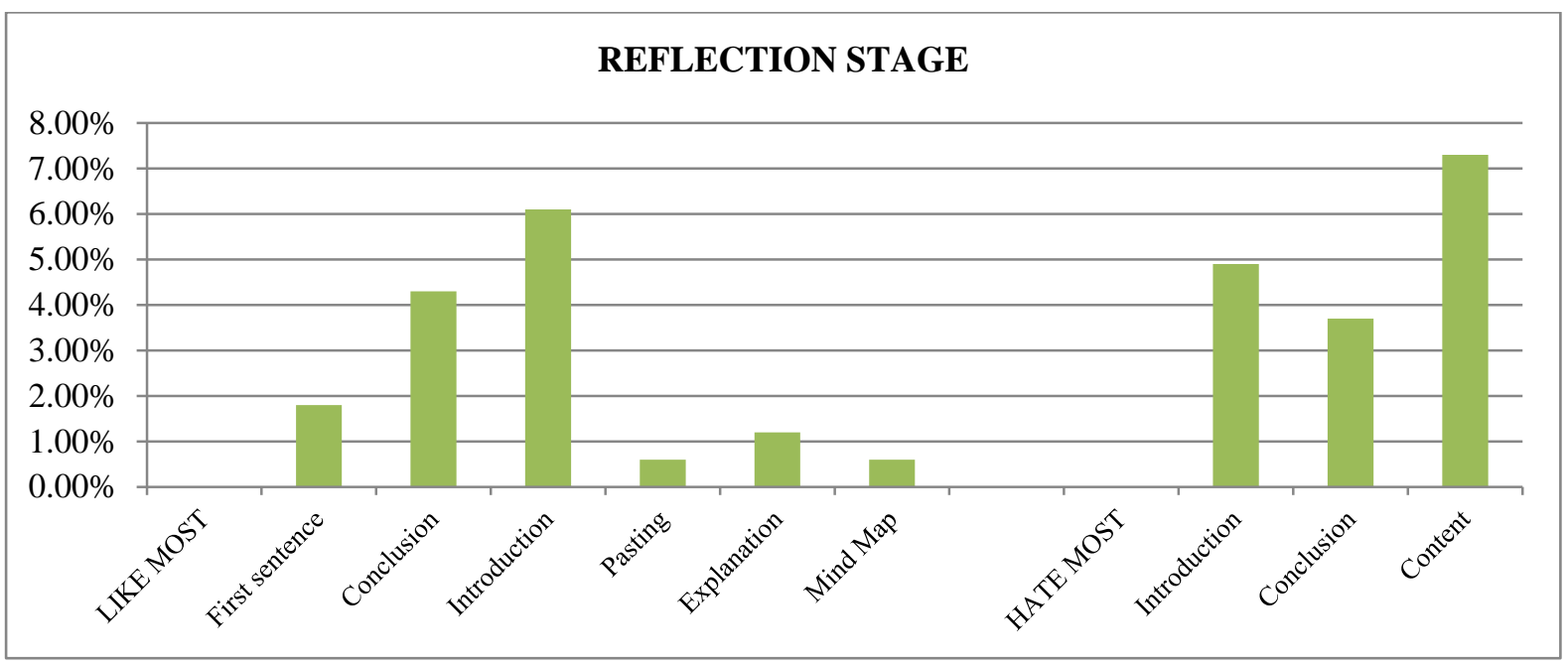

Figure 10. Reflection stage

Table and Figure 8 depict the comments made for the Reflection stage. This stage is divided into 2 sections- the first section reveals what the students liked most and the second reveals what they hated most about this jigsaw writing activities. $6.1 \%$ and $4.3 \%$ said they loved the Introduction and Conclusion respectively. This is because these two paragraphs were not done alone; they did it as a group. However, $7.3 \%$ said they hated "content" part. This means the students were still struggling with what to write although they worked in groups.

Answer to (c)

How does Cooperative Learning influence Jigsaw Writing? 


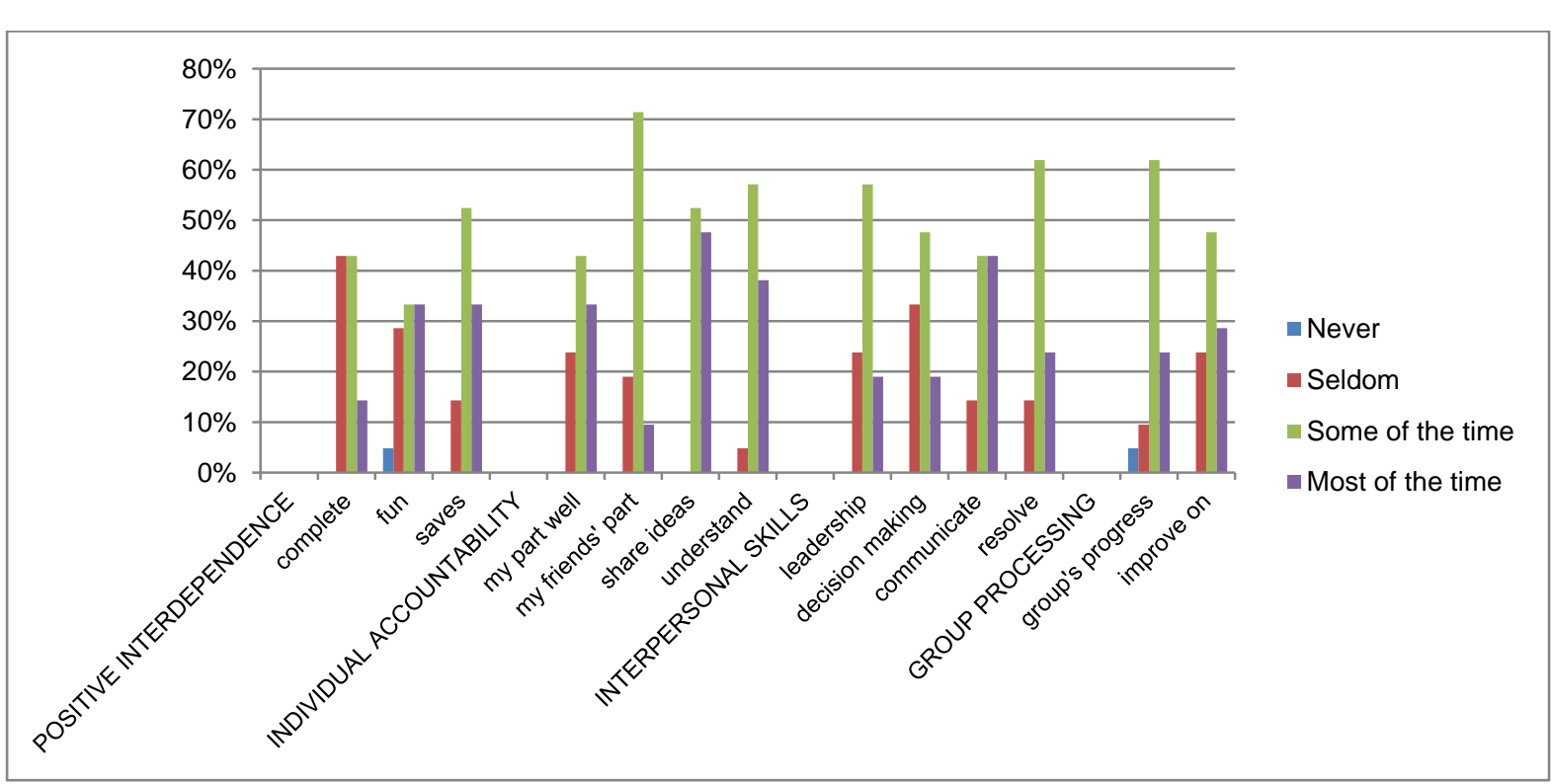

Figure 11. percentage for cooperative learning

The percentage for cooperative learning is shown in Figure 9 above. Students were reported to have enjoyed $(33.3 \%)$ the jigsaw activity and found that the cooperative learning helped save time (33.3\%). The students also agreed that jigsaw writing activities allowed them to share ideas $(47.6 \%)$ besides being able to understand (38.1\%) how their friends did their work. Cooperative learning has also taught them to communicate $(42.9 \%)$ with their friends. Studies by Vygotsky (Mc Leaod, 2010), Elola and Oskoz (2010) and Mulligan and Garofola (2011) have proven how beneficial cooperative learning is in the classroom. Besides gaining ideas from peers, students are also able to improve on their content skills, as well as communicative strategies as a result of the interaction.

\section{CONCLUSION}

\section{Summary of findings}

This research has shown yet another benefit of jigsaw classroom by Aronson (1979). What makes this research different is that the concept of jigsaw classroom is extended into the writing classroom.

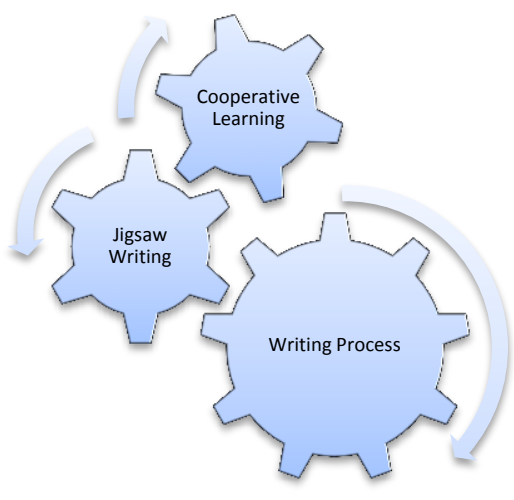

Figure 12. Summary of findings

The summary of this research is shown in Figure 12. Although the results of this study cannot be generalized for all ESL students learning how to write, the techniques used in the action research cycle can be used in the ESL writing classroom.

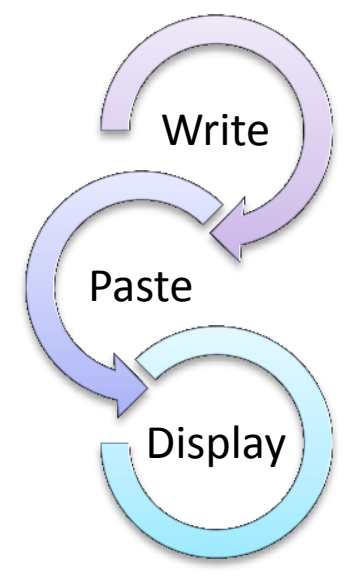


Figure 13. Jigsaw writing stages

Throughout the action research, three prominent stages were identified. They are (1) Write, (2) Paste and (3) Display. The first stage of this jigsaw writing was the writing stage where students were assigned their own individual parts to write-individual paragraphs. Then they proceeded to combine all the individual efforts and paste the paragraphs into a long scroll -the complete essay. The final stage is the part where students display their scroll for the class to see and for it to undergo feedback and revision.

\section{Pedagogical implications}

This has been a small, exploratory Action Research. It would be better if Jigsaw writing be carried out to more students, mixed variety of courses and levels, age group as well as gender.

\section{REFERENCES}

Andrews, A. \& Caster. (2008). Collaborative writing: An Autoethnographic Study of Co-Authorship. USC Upstate Undergraduate Research Journal, Vol1, 1-6.

Aronson, E. \& Bridgeman, D. (1979). Jigsaw groups and the desegregated classroom: In Pursuit of Common Goals. Personality and Social Psychology Bulletin, 5(4), 438-446. Retrieved from

http://www.psychwiki.com/wiki/Aronson,_E ,_\%26_Bridgeman,_D._(1979)._Jigsaw_groups_ and_the_desegregated_classroom:_In_pursuit of_common_goals._Personality_and_Social_Psy chology_Bulletin,_5(4),_438-446.

Aronson, E. (1978). The Jigsaw Classroom. Retrieved from https://www.jigsaw.org/

Crawford, L.W. (2004). Strategies for writers' researchbased program for writing success. Retrieved from

http:www.zaner.blosser.com/pdf/LA151.

Elola, I. \& Oskoz, A. (2010). Collaborative writing: Fostering Foreign Language and Writing
Conventions Development, 14(3), 51-71, ISSN 1094-3501

Felder, R. M. \& Brent, R. (2009). Cooperative learning. Retrieved from http://www4.ncsu.edu/unity/lockers/users/f /felder/public/Student-Centered.html

Grabe, W. \& Kaplan, R. B. (1996). Theory and practice of writing - an applied linguistic. USA: Addison, Wesley, Longman

Johari, S. K. (2004). Second language writing: From Knowledge to Application. Proceedings of the National Seminar on English Teaching. Bangi: Penerbitan UKM

Larsen \& Freeman, D. (2000). Techniques and principles in language teaching ( $2^{\text {nd }}$ edition). Oxford: Oxford University Press.

McLeoad, S. (2010). Zone of Proximal Development. Developmental psychology. Retrieved form http://www.simply psychology.org/Zone-ofProximal-Development.html

Mulligan, C. \& Garofalo, R. (2011). A collaborative writing approach: Methodology and Student Assessment. The Language Teacher. Feature Article, 35(3), 5-10. Retrieved from http://jaltpublications.org/t/l

Rahmat, N. H. (2008). Peer review in the writing classroom: A Case Study of Written and Oral Stances on Revision Behaviour among ESL Writers. Doctoral Thesis Dissertation. Malaysia National University. Retrieved from http://malrep.uum.edu.my/rep/Record/uitm. eprints. 4311

Tompkins, G. E. (1990). The writing process in teaching writing: Balancing Process and Product. Ohio: Merill Publishing Co.

WAC Clearinghouse. (2015). Why consider collaborative writing assignments? WAC Clearinghouse. Rertrieved from http: //wac.colostate.edu/intro/pop21.cfm

Whitehead, J. (1985). An analysis of an individual's educational development: The Basis for Personally Oriented Action Research, in: Shipman, M. (ed.) Educational Research: principles, policies and practices, Lewes, Falmer.

WiseGeek. (2014). What is a scroll? Retrieved from http://www.wisegeek.com/what-is-ascroll.htm 